\title{
VOLUME 12
}

1937

\section{PHILOSOPHY}

THE JOURNAL OF THE BRITISH INSTITUTE

OF PHILOSOPHY

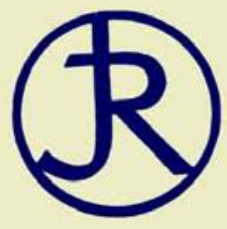




\section{PHILOSOPHY}

(THE JOURNAL OF THE BRITISH INSTITUTE OF PHILOSOPHY) 


\title{
PHILOSOPHY
}

\section{(THE JOURNAL OF THE BRITISH INSTITUTE OF PHILOSOPHY)}

\author{
EDITED BY \\ SYDNEY E. HOOPER \\ WITH THE ASSISTANCE OF \\ S. ALEXANDER \\ JULIAN S. HUXLEY \\ J. H. MUIRHEAD \\ C. D. BROAD \\ F. B. JEVONS \\ BERTRAND RUSSELL \\ WILLIAM BROWN \\ M. GINSBERG \\ G. DAWES HICKS \\ HAROLD J. LASKI \\ L. S. STEBBING \\ A. D. LINDSAY \\ G. F. STOUT \\ JOHN S. MACKENZIE \\ A. E. TAYLOR
}

CLEMENT C. J. WEBB

VOL. XII.-I937

\author{
LONDON : \\ MACMILLAN \& CO., LIMITED \\ ST. MARTIN'S STREET, W.C. \\ 1937
}

Reprinted with the permission of the Royal Institute of Philosophy, London JOHNSON REPRINT CORPORATION Johnson Reprint Company Limited 111 Fifth Avenue, New York, N.Y. 10003 Berkeley Square House, London, W. 1 
First reprinting, 1965, Johnson Reprint Corporation Printed in the United States of America 


\section{CONTENTS OF VOLUME XII}

\section{ARTICLES}

AARoN, R. I.-Great Thinkers: (X) John Locke Allan, D. J.-Nature, Education and Freedom according to Jean-Jacques Rousseau

Bartlett, F. C.-Some Problems in the Psychology of Temporal Perception

Chapman, H. W.-Colour -

Elwell-Sutton, A. S.-The Great Tao

EwING, A. C.-Some Points in the Philosophy of Locke - $-{ }_{-}-{ }_{-}$

Garvie, A. E.-Reflections on Plato's Republic - - - - - - -

Gomperz, H.-Some Simple Thoughts on Freedom and Responsibility

GrahaM, J. C.- "Both God and Man"

Hallet, H. F.-On Being a Philosopher -

JEssop, T. E.-Great Thinkers: (XI) Bishop Berkeley

KNox, T. M.-Action

LAING, B. M.-Great Thinkers: (XII) David Hume

LAIRD, J.-Contemporary British Realism - - - - - - - - - - $\quad$ I62

LAMONT, W. D.-Philosophy, Science and Value - - - - - - $\quad$ - 432

Montague, W. P.-The Story of American Realism - - - - - - $\quad$ I40

MURE, G. R. G.-Oxford and Philosophy - - - - - - - - - $29 \mathrm{I}$

Muirhead, J. H.-Where is Philosophy Going? - - - - - - - $\quad 387$

Percy, Lord Eustace.-Culture, Philosophy and Faith - - - - I3I $^{\mathrm{I}}$

QUick, O.-Knowledge, Action and Religion - - - - - - - $\quad$ - 208

RADHAKRISHNAN, SIR S.-Progress and Spiritual Values - - - - - 259

Ritchie, A. D.-Errors of Logical Positivism - - - - $\quad$ - $\quad$ - $\quad$ - 47

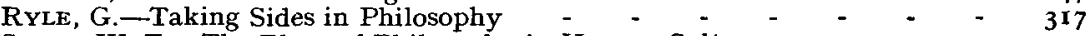

Stace, W. T.-The Place of Philosophy in Human Culture - - - - 302

\section{DISCUSSION}

York, The ARchbishop of.-Both God and Man-A Reply - - - - 222

\section{PHILOSOPHICAL SURVEYS}

Philosophy in Germany.-Helen Knight -
Philosophy in Italy. - - G. de Ruggiero -

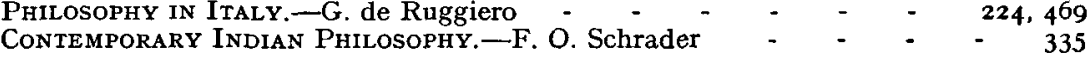

\section{NEW BOOKS}

AARon, R. I. -John Locke (A. C. Ewing) - - - - - - $\quad-\quad$ - $\quad-\quad 47^{8}$

Aaron, R. I., and GiBB, J. (Editors). - An Early Draft of Locke's Essay, together with Excerpts from his Journals (J. Laird)

Allen, A. H. B.-The Self in Psychology (A. W. Wolters) - - - - $\quad-\quad 37^{8}$

BARKER, E.-Education for Citizenship (F. A. Cavenagh) - - - - 503

Bartle t, E. M. Types of Aesthetic Judgment (Listowel) - - - - 492

Beale, W. J.-Divine Causation; A Critical Study Concerning "Intermediaries" (E. S. Waterhouse) - $\quad-\quad-\quad-\quad-\quad-\quad-\quad$ - 504

Berdyaev, N. (Tr. by Duddington, N.). -The Destiny of Man (C. C. J. Webb) $47^{2}$

Bishop, M.-Pascal: The Life of Genius (E. S. Waterhouse) - - - 495

BRIGHTFIELD, M. F.-The Issue in Literary Criticism (R. G. Collingwood) - $\quad$ II4

Brown, W.-Mind, Medicine and Metaphysics. The Philosophy of a Physician (F. Aveling) - 


\section{CONTENTS}

Brunner, E.-God and Man: Four Essays in the Nature of Personality (E. S. Waterhouse)

Chestov, L. (Tr. du Russe par Rageot, T., et de Schloezer, B.).-Kierkegaard et la philosophie existentielle (D. M. Emmet) -

Cort, S.-The One Sure Foundation for Democracy (J. A. Hobson) - -

Collingwood, R. G.-Human Nature and Human History (W. G, de Burgh)

CoRnford, F. M.-Plato's Cosmology (G. C. Field)

Crossman, R. H. S.-Plato To-day (G. C. Field) -

FeIbleman, J.Christianity, Communism, and the Ideal Society: A Philosophical Approach to Modern Politics (A. E. Garvie)

Gauss, H.-Plato's Conception of Philosophy (W. G. de Burgh) - - -

George, W. H.-The Scientist in Action (G. B. Brown) - - - -

Gotshalk, D. W.-Structure and Reality: $A$ Study of First Principles (J. Laird)

Gough, J. W. - - The Social Contract; $A$ Critical Study of its $\overline{\text { Development }}$ (O. de Selincourt)

HaEcker, T. (Tr. by Dru, A.).-Søren Kierkegaard (C. C. J. Webb) -

HANNAY, H. - Roger Fry and Other Essays (Listowel) - - - - -

HARDIE, W. F. R. $-A$ Study in Plato (G. C. Field) - - - - -

Hartshorne, C., and WeIss, P. (Editors).CCollected Papers of Charles Sanders Peirce: Vol. VI. Scientific Metaphysics (L. S. Stebbing) - -

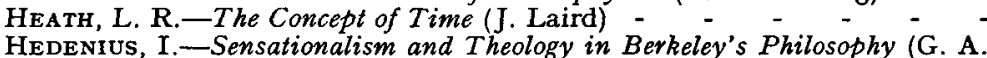
Johnston)

Hertzler, J. O.-The Social Thought of the Ancient Civilizations (M. Kaye)

Hicks, G. DAwEs.-The Philosophical Bases of Theism (C. C. J. Webb)

HockING, W. E.-The Lasting Elements of Individualism (O. de Selincourt)

Horner, I. B.-The Early Buddhist Theory of Man Perfected: A Study of the Arahan (E. S. Waterhouse)

HorT, G.-Sense and Thought: $A$ Study in Mysticism (L. W. Grensted)

JAHN, A.-The Silver World: An Essay on the Ultimate Problems of Philosophy (J. Laird)

JoRDAN, W. K.- The Development of Religious Toleration in England, from the Accession of James $I$ to the Convention of the Long Parliament (E. S. Waterhouse)

Kie RKEGAARD, S. (Climacus, J.) (Tr. by Swenson, D. F.).-Philosophical Fragments, or a Fragment of Philosophy

Knox, I.—The Aesthetic Theories of Kant, Hegel, and Schopenhauer (Listowel)

LAIRD, J.-Recent Philosophy (C. E. M. Joad) - - - - - -

L Growth of the Mind in Relation to Culture (R E Stedman)

LAURILA, K. S.-Aesthetische Streitfragen (Listowel) - - - - - - $\quad 242$

LICHTIGFELD, A.-Philosophy and Revelation in the Work of Contemporary Jewish Thinkers (A. E. Garvie) - - - - _ - - -

Lovejoy, A. O.-The Great Chain of Being: $A$ Study of the History of an Idea (B. M. Laing)

MACFIE, A. L.-An Essay on Economy and Value (J.- - - - - - - - II3

Mackenzie, John Stuart. Edited by his Wife (H. J. W. Hetherington) - - 377

MACLEAN, K.- John Locke and English Literature of the Eighteenth Century (R. I. Aaron)

MANNHEIM, K.-Ideology and Utopia: An Introduction to the Sociology of Knowledge (M. Kaye) - $\quad-\quad$ - $\quad-\quad$ - $\quad-\quad$ -

MARETT, R. R.-Head, Heart and Hands in Human Evolution (F. A. E. Crew)

MAUND, C.-Hume's Theory of Knowledge: $A$ Critical Examination (J. D. Mabbott)

Mossner, E. C. -Bishop Butler and the Age of Reason: A Study in the History of Thought (E. S. Waterhouse)

MUeLleR, G. E.-Philosophy of our Uncertainties (R. E. Stedman) - -

MuKerJeE, R.-Theory and Art of Mysticism (M. Smith) - - - - 497

Murray, A. H.-The Philosophy of James Ward (J, Laird) - - - - - 352

MYers, C. S.-In the Realm of Mind: Nine Chapters on the Applications and Implications of Psychology (F. Aveling)

NIEBUHR, R. - An Interpretation of Christian Ethics (E. S. Waterhouse) - $\quad 3^{0}$

Patch, H. R.-The Tradition of Boethius (C. C. J. Webb) - - - - - 118

PAton, H. J.-Kant's Metaphysic of Experience (T. D. Weldon) - $\quad$ - 99

PEgIS, A. C.-St. Thomas and the Problem of the Soul in the Thirteenth Century (L. J. Walker) 


\section{CONTENTS}

PERRY, R. B.-The Thought and Character of William James, as revealed in Unpublished Correspondence, together with his Published Writings (J. Laird)

Prelps, H. A.-Principles and Laws of Sociology (M. Kaye) - - -

Planck, M. (Tr. by Johnston, W. H.).-The Philosophy of Physics (G. B. Brown)

Ponsonby, A. (Lord Ponsonby of Shulbrede)-Life Here and Now: Conclusions Derived from an Examination of the Sense of Duration (R. E. Stedman)

Prall, D. W.-Aesthetic Analysis (Listowel)

PratT, J. B.-Personal Realism (J. Laird) -

Przywara, P. E. (Tr. by Bouquet, A. C.).-Polarity: A German Catholic's Interpretation of Religion (L. J. Walker)

Purcell, V.-Problems in Chinese Education (G. E. Taylor) - -

Radhakrishnan, Sir S.-The World's Unborn Soul (J. H. Muirhead) -

RAY, B.-Consciousness in Neo-Realism (R. E. Stedman) - - -

Reid, L. A.- Creative Morality (W. D. de Burgh)

ReIK, T. (Tr. by Green, M. M.).-Surprise and the Psycho-Analyst: $A$ Study of the Conjecture and Comprehension of Unconscious Processes (B. D. Hendy)

SanTAYANA, G.-Obiter Scripta: Lectures, Essays and Reviews (J. Laird) -

Schelling, F. W. J. (Tr. by Gutmann, J.). Of Human Freedom (W. A. Sinclair)

SORLEY, W. R. - A History of English Philosophy (A. C. Ewing) - - - -

STEELE, R.-Opera hactenus inedita Rogeri Baconi. Fasc. XIV (A. E. Taylor)

Strauss, L. (Tr. by Sinclair, E. M.).-The Political Philosophy of Hobbes: Its Basis and Genesis (M. Oakeshott)

SwABEY, M. C-Theory of the Democratic State (J. A. Hobson)

SwaBey, W. C.-Being and Being Known: An Introduction to Epistemology and Metaphysics (J. Laird)

Taube, M.-Causation, Freedom and Determinism: An Attempt to Solve the Causal Problem through a Study of its Origins in Seventeenth-Century Philosophy (J. Laird)

Ushenko, A. P.-The Philosophy of Relativity (H. Dingle) - - - - -

Various Authors.-Hommage à Monsieur le Professeur Maurice de Wulf

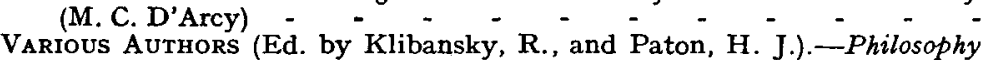
and History: Essays presented to Ernest Cassirer (T. E. Jessop) - -

VARIous AUthors.-The Social Sciences: Their Relations in Theory and in Teaching (O. de Selincourt) - - - - - - $-{ }^{-}-{ }_{-}^{-}$

VARIous Authors. -What Can Philosophy Determine? (Aristotelian Society. Supplementary Vol. XV) (J. H. Muirhead) - - - - - -

WEINBeRG, J. R.-An Examination of Logical Positivism (H. H. Price)
WILD, J.-George Berkeley: $A$ Study of his Life and Philosophy (G. A. Johnston)

PAGE

104

361

$24^{I}$

375

242

369

243

$37^{\circ}$

232

244

493

$34^{2}$

366

374

378

359

347

239

500

498

490

$35^{\circ}$

373

I07

377

I 16

228

I 12

\section{CORRESPONDENCE}

Cross, F. L.

Eastgate, G.

RerchenBach, $\mathrm{H}$.

Ushenko, A. P. -

\section{$-\quad-\quad-\quad-$}

508

508

I2 I

507

\section{INSTITUTE NOTES}

Evening Meetings: Lent Term Michaelmas Term

Lecture Courses: Lent Term

Michaelmas Term

Presidential Address (Summary) 


\section{CONTENTS}

MISCELLANEOUS

PAGE

Address by Viscount Samuel to the Inaugural Meeting of the Ninth International Congress of Philosophy -

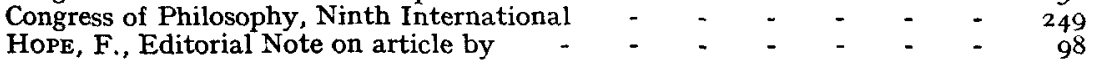

viii 